\title{
The Organizational Behavior and Culture of Workers Form Transactional Expenses in Agrarian Economy: Practice of Re- searches in the Siberian Region
}

\author{
Victor F. Stukach ${ }^{1 *}$, Nadezhda A. Anikina ${ }^{2}$, Vitaliy M. Pomogaev ${ }^{3}$ \\ ${ }^{1}$ Department of Marketing and Management, Federal State Budgetary Educational Institution of Higher Education Omsk State Agricul- \\ ture University, Omsk, Russia \\ ${ }^{2}$ Economic Development, Federal State Budgetary Educational Institution of Higher Education Omsk State Agriculture University \\ Omsk, Russia \\ ${ }^{3}$ Department of Economy and Finance, OAO OAK-Transportnie samo-lety (JSC, United Aircraft Company - Transport airplanes) Omsk, \\ Russia
}

"Corresponding author: Victor F. Stukach, Professor of the department of marketing and management, Federal State Budgetary Educational Institution of Higher Education "Omsk State Agriculture University named after P. A. Stolypin", Institutskaya ploshchad’ 1, Omsk, 644008, Russia. Tel: +73812652788; Email: vf.stukach@omgau.org

Citation: Stukach VF, Anikina NA, Pomogaev VM (2017) The Organizational Behavior and Culture of Workers Form Transactional Expenses in Agrarian Economy: Practice of Researches in the Siberian Region. J Agr Agri Aspect: JAAA-121. DOI: $10.29011 / 2574-2914.000021$

Received Date: 23 September, 2017; Accepted Date: 22 November, 2017; Published Date: 27 November, 2017

\begin{abstract}
Background/Objectives: The objective of this research is to study the parameters of existent organizational culture in agrarian sector as a resource for forming social capital and its influence on transactional costs formation.

Method/Statistical analysis: In an attempt to reach desired objective, such analytical methods as sociological and expert interviews, content and problem-oriented analysis were applied. Behavior characteristics investigation was based on G. Hofstede's parametrical models adapted to agriculture. Methods we used were intended to achieve the following goals: to reveal the essence of transactional costs of the agrarian sector with consideration of peculiar features in the field, to identify the specifics of behavioral settings and values, the specifics of costs pattern within the regional institutional interaction framework and to analyze cultural codes and path dependence problem of the agrarian sector.

Findings: On the materials of the agrarian sector of the regional economy, the parameters of existent organizational culture were studied; transaction costs specifics shaped by cultural component were identified; research on cultural codes was conducted. The following special features of the agrarian sector were revealed: excessive production cycle, unequal income distribution during a year, natural and climatic conditions dependence. Outlined above features indicate the need in state support and well-developed communication system. The cluster of cultural components denotes a cultural code which reflects the high level of roles differentiation between man and women; prevailing collective consciousness; tendency to avoid situations of uncertainty and clearly established courses of actions and regulations; low self-control level and poor level of the need to satisfy basic needs. Specific transactional costs shaped by cultural determinants comprise the following: costs of data searching, processing and storage, costs of negotiating and contracting costs; coordination costs; politicization costs; costs of collective decision making; lost profits costs.

1.4. Applications/Improvements: Present findings might help to solve the problem of overcoming informal institutional limitations, also it could be applied for development and accumulation of social capital, implementation of best informal practices on costs reduction by elimination of lost profits, functioning quality increase of transactional sector of economy in general.
\end{abstract}




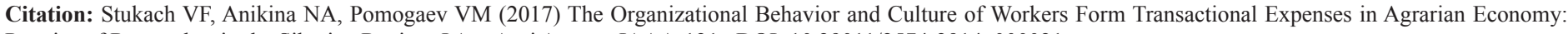
Practice of Researches in the Siberian Region. J Agr Agri Aspect: JAAA-121. DOI: 10.29011/2574-2914. 000021

Keywords: Agrarian sector; Institutions, Organisational culture, Social capital, Transactional costs

\section{Introduction}

The present research is aimed at studying the parameters of existing organisationalcultureasaresource forforming socialcapital, traditions, values, symbols, general approach and mentality of the population. During the process of the social and economic research based on the agricultural sector of the economy of the region, the amount of culture influence on forming an organisational climate on the territory was assessed and practical recommendations were provided. Given recommendations were designed to overcome the developmental misbalance of transactional and transformational sectors of economy and informal institutional limitations. Also, those recommendations may be applicable for social capital development and accumulation, implementation of best informal practices on costs reduction by elimination of lost profits.

One of the reasons of the Russian economy growing slowly is the high level of transaction costs. The economy has reached the level where market transaction services require disproportionately high resources and there are no quality changes represented by outrunning growth of profit as a result of commercial activities $[1,2]$. According to the institutional theory, transaction costs define parameters of relations between subjects including market transactions losses, while being the result of conforming to general rules of institutions. Thus, the more effective economic institutions are, the more they contribute to minimising transaction costs $[3,4]$.

\section{State of the art}

Until the beginning of the 70 s of the previous century, economic science held a certain idea about the factors of economic growth. According to this idea, accumulated wealth in the form of available resources, human capital and manufacturing investment played the major role. Institutionalist economists included existent formal and informal institutions as a prerequisite for stability and dynamic development of the country. Recently, scientists have commenced regarding social capital as a growth and stability resource. For example, in L. Polischuk's view "the vector of state transaction policy aimed at developing social and cultural characteristics reduces uncertainties, increases the effectiveness of interaction between businesses and the government, lowers administrative barriers, helps to fight opportunism, enhances the effectiveness of infrastructure institutes, etc."[5].

Social capital includes some well-known constituents: it is based on trust, codes and values shared in the society and various social networks. The government's aim is to provide public goods. As D. North and J. Wallis noted in their works, "as soon as people are unable to manage this well, they 'invite' the government. At the same time, effective, regulated, uncorrupted government is a public good itself and there is no government body which controls this public good. Such a public good as an effective government can be provided only by society itself. For this reason, if society is organised enough and possesses a lot of social capital, the government functions well"'[6].

Transaction costs are the costs incurred in the coordination of market processes in an external environment, in the hierarchical structure of a firm and implied costs such as loss as a result of all kinds of transactions. Uneconomic factors which form transaction costs are informal institutions and negative activities which are done by people and influence their behavioural principles [7].

In the view of the current ideas about the institutional economics, a characteristic of an informal institution is the fact that it is not founded by the government but is a result of interaction between individuals. Institutional constraints are the system of values, principles and cultural codes of the economy, which together with formal institutions determine the actions of subjects in the social and economic environment. Being a social capital resource, organisational culture forms traditions, values, symbols, general approaches and mentality of organization's members and influences the creation of social capital and employees' perception of a situation.

Social capital affects the economy and business behaviour horizontally and vertically. As regards the horizontal channel, the experience of reaching an agreement and cooperative regulation of relations, self-management and trust allow eliminating contradictions in business communication without government engagement that decreases transaction costs. Transaction participants of informal institutions are effective in commercial interaction without resorting to government help. The vertical channel of influence ensures synchronisation with government bodies and the quality of government management $[8,9]$.

There are various classifications of organisational culture. Among the most famous are the classifications of G. Hofstede, T. Deal and A. Kennedy, R. Blake and J. Mouton, Ch. Handy, K. Cameron and R. Quinn and others. K. Cameron and R. Quinn built the methodology based on competing values. They suggest two dimensions: 1) flexibility, discretion and dynamism of an organisation at one end of a scale and stability, order and control on the other; 2) internal orientation, integration and unity at one end and external orientation, differentiation and rivalry on the other. Both dimensions form four squares of different framing values, reflecting types of organisational culture: hierarchy, clan, market and adhocracy [10].

American sociologistCh. Handy's methodology distinguishes 4 types of culture with the following parameters: organisation's business character and structure; relationships between an individual and an organisation; the process of distribution of power 


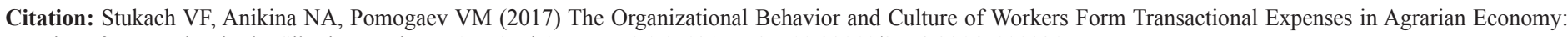
Practice of Researches in the Siberian Region. J Agr Agri Aspect: JAAA-121. DOI: 10.29011/2574-2914. 000021

and personal values. According to the author, the types of culture are the culture of power, the culture of role, the culture of task and the culture of person $[11,12]$.

G. Hofstede's classification of organisational culture was developed in the $80 \mathrm{~s}$ of the previous century. The basis of the model was a global-scale research conducted by a transnational corporation IBM. More than 116 thousand employees in 40 countries took part in the survey. The suggested classification helps to understand the mechanism of correlation between organisational behaviour and culture. This classification is the most popular among scientific community due to the set of familiar parameters used for analysing organisations of different cultures regardless the country where they are based in [13-15]. G. Hofstede's findings are relevant for managers of different levels in any country including Russia. The relevance is due to the current labour market having general characteristics: the drift of unskilled labour, growing migration processes, foreign companies entering the market and changing game rules. It is quite obvious that under the condition of immigration being poorly regulated by top management and government bodies there is a problem of adapting people from different cultures both at the level of business and region-wide.

In terms of our research, G. Hofstede's classification of behavioural characteristics is favourable for studying the interrelation of organisational behaviour and culture. The classification has the following parameters: individualism vs. collectivism; power distance (the amount of participation in making decisions concerning everybody); uncertainty avoidance; masculinity vs. femininity; long-term orientation and indulgence vs. restraint. According to G. Hofstede's classification, the estimation of the interrelation between organisational behaviour and culture and the present situation in the society, country or region is the basis for assessing the condition of social capital.

\section{Methods Applied}

The research on cultural codes of the agricultural sector of the region's economy was conducted to find out the specifics of transaction costs. The influence of cultural determinants (informal institutions) on the content and structure of the transaction component of the agricultural sector of the region's economy was under study. In order to reach the aims of the research the following objectives were set:

- To find out the specifics of transaction costs regarding the peculiarities of the agricultural sector, behavioural principles and values, and the structure of costs in institutional interaction in the region;

- To determine cultural codes and path-dependence problem in the agricultural sector.

The stages of the research were:
1. Questioning specialists of agricultural organisations and city government.

2. Processing and systematisation of the collected data.

3. Analysing the results of the conducted research.

4. Describing and graphically representing the research.

In the present research the problem-oriented analysis was applied. It is the analysis of business activity of an organisation which identifies problems, determines the reasons and finds solutions [16]. There were 93 respondents, who took part in the questionnaire, with branch managers of agricultural organisations and heads of administration of agriculture of municipal areas among them. The research was conducted in 17 municipal areas of Omsk region in three natural and climatic zones.

The study of behavioural characteristics was based on the parametric model of $\mathrm{G}$. Hofstede adapted for agricultural specifics [17-19]. The research was based on six parameters of culture dimensions: power distance, uncertainty avoidance, individualism vs. collectivism, masculinity vs. femininity, long-term vs. short-term orientation and indulgence vs. restraint. The methods of assessing cultural components are: 1) there are six parameter block models in the questionnaire and each question corresponds to a certain cultural characteristic; 2) based on the chosen option the answer is referred to one of the parameters of cultural characteristics; 3) quantitative and qualitative characteristics were determined by comparing the received data within specified intervals.

\section{Results and Discussion}

The particularities of the agricultural sector and the influence of informal institutions form the specific interaction in the agroindustrial business. Table 1 shows intervals of cultural dimensions and characteristics of their expression degree. Thus, duration of manufacture cycles, unequal allocation of profits throughout the year, dependence on natural and climatic conditions determine the need for government support and developed communication system. The higher the level of power distance is the more complicated the interaction becomes. Power distance is affected by such cultural preferences and informal practices as people's attitude to hierarchy, relationships with subordinates, attitude to older generations and others.

The set of cultural characteristics presents the cultural code which reflects the constituents of informal institutions. The conducted research revealed:

- $\quad$ high degree of differentiation between male and female roles;

- collective consciousness dominates in relationships with its peculiarity being vertical collectivism and weak rivalry;

- $\quad$ uncertainty avoidance and the need for order and rules; 


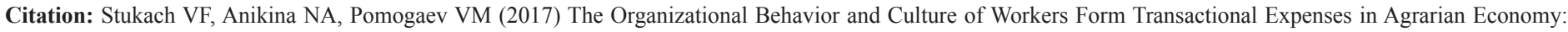
Practice of Researches in the Siberian Region. J Agr Agri Aspect: JAAA-121. DOI: 10.29011/2574-2914. 000021

- the need for clarity regarding future;

- $\quad$ low level of self-control and the need for satisfaction of basic desires.

\begin{tabular}{|c|c|c|c|}
\hline \multirow{2}{*}{$\begin{array}{c}\text { Cultural } \\
\text { dimensions } \\
\text { exponent }\end{array}$} & \multicolumn{2}{|c|}{ Exponent intervals/characteristics of expression } \\
\cline { 2 - 4 } degree
\end{tabular}

Table 1: Intervals of cultural dimensions and characteristics of their expression degree.

Dimensions values of cultural characteristics are represented in Table 2.

\begin{tabular}{|c|c|c|}
\hline $\begin{array}{c}\text { Cultural } \\
\text { dimensions }\end{array}$ & $\begin{array}{c}\text { Dimensions } \\
\text { values }\end{array}$ & $\begin{array}{c}\text { Parameter characteristics } \\
\text { (degree) }\end{array}$ \\
\hline $\begin{array}{c}\text { Masculinity vs. } \\
\text { femininity }\end{array}$ & 0,62 & Masculinity \\
\hline $\begin{array}{c}\text { Individualism vs. } \\
\text { collectivism }\end{array}$ & 0,43 & Collectivism \\
\hline $\begin{array}{c}\text { Uncertainty } \\
\text { avoidance }\end{array}$ & 0,74 & High degree of power distance \\
\hline $\begin{array}{c}\text { Power distance } \\
\text { avoncertainty }\end{array}$ \\
\hline $\begin{array}{c}\text { Time orientation } \\
\text { Indulgence vs. } \\
\text { restraint }\end{array}$ & 0,62 & Long-term orientation \\
\hline
\end{tabular}

Table 2: Dimensions values of cultural characteristics in the agricultural sector.

Thus, the whole complex of cultural quantitative characteristics provides an idea of cultural code in the Omsk region agricultural sphere of the economy. The society is represented by collectivist groups with individualism being barely developed.
This reflects people's inclination to avoid taking responsibility for the results of their work. There is no capacity for individual selfexpression, rivalry and developing competitive advantages while the capacity for working in a team and for collective thinking with the focus on the common result is well-developed and forms trust in a close setting. High degree of uncertainty avoidance indicates the need for precision, clarity, well-working rules, situation regulation, planning and information. Uncertainty avoidance is a cultural characteristic which is also determined by the peculiarities of the agricultural sector that are the dependence on natural and climatic conditions and the entwinement of manufacturing and biological processes. Power distance implies complicated hierarchy in government and society relationship system, unequal distribution of profits and low level of trust. Specific transaction costs resulting from informal institutions, practices and cultural determinants include information search, procession and storing costs, negotiations and contracts execution costs, coordination and politicisation costs, costs of collective decision-making and lost earnings costs.

Problem-oriented approach in analysis revealed the following:

- The agricultural sector is unable to successfully develop without support, but $22 \%$ of respondents point out that government support is not effective.

- $\quad 47 \%$ of respondents expressed the lack of trust towards the government, and $23 \%$ had a positive attitude to the government regarding them as a legal protection, security guarantee and financial support.

- According to $87 \%$ of respondents, it is beneficial to establish effective communication between society and government, which would allow speaking about problems openly and contribute suggestions. This indicates a potential opportunity to decrease the existing power distance.

- The main spheres of government support should be the following: development of in-house raw material processing - 48\%; production distribution assistance - 47\%; development of workforce capacity in the country and creating a developed, modern and social infrastructure - 49\%; development of legal support in order to protect agricultural manufacturers against partners' opportunism and dishonesty of distribution chains in particular - $17,2 \%$ of respondents.

The analysis of social and cultural characteristics of the society in the agricultural sphere helped to determine cultural codes of the economy and path-dependence problem conditioned by informal institutions and negative informal practices.

\section{Conclusions}

Transaction costs reduction is promoted by the development and reinforcement of social capital, determining cultural codes of the 


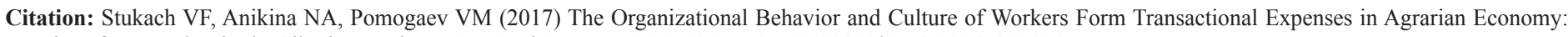
Practice of Researches in the Siberian Region. J Agr Agri Aspect: JAAA-121. DOI: 10.29011/2574-2914. 000021

economy and their regulation. The development of communicative interaction of market participants, science and production and commercial activities contributes to lowering transaction costs in the form of lost earnings, information searching costs and bounded rationality.

Lowering administrative barriers will change the structure of transaction costs by increasing transaction cost of overcoming opportunistic behaviour and reducing lost earnings. Decreasing transaction costs in the form of lost earnings and strengthening trust towards institutions will be fostered by improving the quality of information, reacting against unregistered statistics and lobbying interests of certain groups and overcoming the limited access.

As experience in conducting agricultural reforms has shown, agricultural organisations are unable to compete successfully outside the cost managing system. Internal and external factors predetermine the necessity of the mechanism of internal transaction costs management being focused on solving the problem of defining the reasonable scale of market activity of an enterprise, increasing the manageability of an economic entity due to implementing a transaction costs management system and formulating unified policy such as rules of conduct of the subject.

The higher the external transaction costs, the more probable it is that a firm will seek an opportunity to replace market transactions with internal ones. On the level of an organisation, it is accomplished by developing internal transaction policy. In conclusion, implementing the described mechanism contributes to overcoming imbalance between the development of transaction and transformation economic sectors, overcoming restrictions of informal institutions, developing and accumulating social capital, strengthening positive informal practices, improving the quality of functioning of the transaction sector of the economy as the whole and reducing costs in the form of lost earnings of organisations.

\section{References}

1. Douglass C North, John Joseph Wallis, Barry R Weingast (2011) Violence and Social Orders. A Conceptual Framework for Interpreting Recorded Human History. Translated in Russian by D. Uzlaner, M. Markov, D. Raskova, A. Raskova. The Gaidar Institute publishing: 480

2. V.I. Maevskiy (2001) Evolution theory and institutes. Vestnik gosudarstvennogo universiteta upravleniya [Bulletin of State University of Management] ("Institutional Economics" series) 1: 19.

3. SV Malakhov (2003) Transactional costs, economic growth and labour supply. Problemy economiki [Economy issues] 9: 90.

4. Ronald H Coase (1993) The Firm, The Market and The Law. Translated in Russian by B. Pinskera. Delo, LTD with contributions from Catallaxy publishing: 192
5. L. Polischuk, R. Menyashev. Issues of economy. Non-profit partnership "Editorial board "Issues of economy". 48-65.

6. John Joseph Wallis, Douglass C. North (1986) Measuring the transaction sector in the American economy; in: Stanley Engermann and Robert Gallman (eds.). Long-term factors in American Economic Growth. Chicago: 95-161.

7. VL Tambovtsev (2001) Institutional market as mechanism of institutional changes. Social sciences and modernity 5: 25-38.

8. GK Triandis (2001) Kul'tura i social'noe povedenie [Culture and social behavior]. Forum: 384.

9. EN Freiman, JK Perskiy (2014) Cluster-network presentation of transaction sector of economy. Fundamental'nie issledovaniya [Fundamental Research] 9: 158-162.

10. A.E. Shastitko (2002) Novaya institucional'naya jekonomicheskaya teoriya [New institutional economics theory]. MSU, faculty of economics. 59.

11. Kim S Kameron, Pobert E Quinn (2001) Diagnostika i izmenenie organizacionnoj kul'tury. [Diagnosis and changing organizational culture]. Translated in Russian under the editorship of I.V. Andreeva. SPB Piter: 320.

12. EV Popov, Konovalov AA (2006) A model of information retrieval costs optimization. Problemy upravleniya [Management issues]. Institut jekonomiki UrO RAN 5: 27-31.

13. VD Pak, NI Nuzhina. Basic typologies of corporate culture. Mezhdunarodniy nauchno-issledovatel'skiy zhurnal [International scientific and research journal]. Social sciences. September. 2015.

14. LF Popova (2014) Analysis of correlation between an organizational structure and situational variables. Vestnik Saratovskogo gosudarstvennogo social'no-jekonomicheskogo universiteta [Bulletin of Saratov State Socio-economics University]3: 18-26.

15. G Hofstede, GJ Hofstede, M Minkov. Cultures and organizations: software of the mind: intercultural cooperation and its importance for survival. New York: McGraw Hill, 3rd ed. 2010. 576;

16. VF Stukach, OV Shumakova (2009) Problemno-orientirovanniy analiz transakcionnyh izderzhek $v$ sel'skohozjajstvennyh organizaciyah [Problem-oriented analysis of transactional costs in agricultural organisations]. Economika [Economy] 3: 48-52.

17. Izmenenie kak koleya [A change as a path]: A. Auzan about illnesses of Russian economy.

18. VF Stukach, AN Anikina (2016) Neformal'nye instituty transaktsionnogo sektora regiona: agroekonomicheskiy aspekt: monografija [Informal institutions of transactional sector of economy: agroeconomical aspect. Omsk SAU: 216

19. VF Stukach, LV Grishaeva, VS Petcevcih, et al. (2015) Infrastruktura: rynochnye instituty, social'naja sfera sela, proizvodstvo [Infrastructure: market institutions, social sphere of rural areas, manufacture]. Omsk SAU. 276. 